\title{
A STUDY ON THE PHENOTYPIC FREQUENCIES OF Rh ANTIGENS AMONG BLOOD DONORS OF A TEACHING INSTITUTION, KERALA
}

\author{
Anjana Mohan1, Sasikala Nadanganan², Meena Dharmadas ${ }^{3}$ \\ 1 Junior Resident, Department of Transfusion Medicine, Government TDMC, Alappuzha, Kerala, India. \\ ${ }^{2}$ Associate Professor, Department of Transfusion Medicine, Government TDMC, Alappuzha, Kerala, India. \\ 3Professor, Department of Transfusion Medicine, Government TDMC, Alappuzha, Kerala, India.
}

\begin{abstract}
BACKGROUND
India is a vast country with several population groups. But minimum data is available about the frequency of different Rh blood group antigens among the Indian population, whereas no data has been reported from Kerala till date. The antigen frequency in a specific population may help us to assess the risk of antibody formation and which in turn may give direction to get an antigennegative compatible blood for patients who have multiple red cell alloantibodies.
\end{abstract}

ABSTRACT

This study was carried out to determine the frequencies of Rh blood group antigens D, C, c, E and e among 500 blood donors.

\section{MATERIALS AND METHODS}

This is a descriptive study done on 500 blood donors who came to the Department of Transfusion Medicine, Govt. T. D. Medical College, Alappuzha. Samples from randomly selected blood donors of nearby areas (both voluntary and replacement) were collected for extended Rh antigen phenotyping during the one-year period of study (February 2015 to January 2016).

\section{RESULTS}

Among the 500 blood donors included in the study, $470(94 \%)$ were males and $30(6 \%)$ were females. 86.6\% (n= 433) of the donors were found to be Rh D positive and the remaining $13.4 \%(\mathrm{n}=67)$ were $\mathrm{Rh} \mathrm{D}$ negative. Most common Rh antigen observed in the study population was e (96.8\%) followed by D (86.6\%), C (80.8\%), c (61\%) and at last E (12.4\%). Out of $433 \mathrm{Rh}$ D positive randomly selected blood donors in the study, the most common phenotype was found to be $\mathrm{R}_{1} \mathrm{R}_{1}(39 \%)$ followed by $\mathrm{R}_{1} \mathrm{r}(34.6 \%)$. Among $67 \mathrm{Rh}$ D negative subjects, $\mathrm{r} r$ was the commonest phenotype (60 out of 67 ).

\section{CONCLUSION}

This study emphasises the need for implementing Rh-phenotyping on routine blood grouping to provide antigen negative compatible blood when in demand. Rh antigenic phenotyping along with antibody identification is crucial, especially in transfusion dependent and multiparous females. It is a vital requirement of a quality transfusion service. From the different reaction patterns observed in this study, the prevalence of probable Rh phenotypes were assessed and it helped to create an antigen negative donor database.

\section{KEY WORDS}

Rhesus Antigens; Alloimmunisation; Antigenic Profile; Rh Phenotyping; Genotyping.

HOW TO CITE THIS ARTICLE: Mohan A, Nadanganan S, Dharmadas M. A study on the phenotypic frequencies of Rh antigens among blood donors of a teaching institution, Kerala. J. Evolution Med. Dent. Sci. 2018;7(43):4678-4681, DOI: $10.14260 /$ jemds/2018/1043

\section{BACKGROUND}

Therapeutic blood transfusion had been attempted from $17^{\text {th }}$ century, but $20^{\text {th }}$ century was the era of monumental discoveries in the field of blood transfusion. ABO blood group system was discovered by Karl Landsteiner in the year of 1901. He described the Blood Groups A, B and O. The Blood Group $\mathrm{AB}$ was described in the year of 1902 by von Decastello and Sturli. In 1941, Landsteiner and Weiner discovered the Rh blood group system. ${ }^{1}$

International Society of Blood Transfusion (ISBT) described 36 human blood group systems. ABO, Rhesus, Kell, Kidd, Duffy, MNS, P, Lewis and Lutheran are the clinically

'Financial or Other Competing Interest': None.

Submission 28-08-2018, Peer Review 30-09-2018,

Acceptance 09-10-2018, Published 22-10-2018.

Corresponding Author:

Dr. Sasikala Nadanganan,

Department of Transfusion Medicine,

Government TDMC,

Alappuzha, Kerala, India.

E-mail: dr.sasikala.n@gmail.com

DOI: $10.14260 /$ jemds/2018/1043 significant blood groups, as these are known to cause Haemolytic Transfusion Reactions (HTR) and Haemolytic Disease of Foetus and Newborn (HDFN). ${ }^{2}$

$\mathrm{ABO}$ and $\mathrm{Rh}$ are the two major blood group systems. Importance of $\mathrm{ABO}$ blood group system is due to the presence of naturally occurring antibodies in the serum of the people who lack the antigen. But importance of $\mathrm{Rh}$ blood group system is because of its high immunogenicity. The term $\mathrm{Rh}$ refers not only to a specific erythrocyte antigen, but also to a complex blood group system that is currently composed of over 50 different antigenic specificities.

$\mathrm{Rh}$ genes are inherited as codominant alleles. Two separate genes for $\mathrm{Rh}$ system are located on chromosome 1. One gene RHD encodes for the D antigen and a second gene RHCE, which encodes for a combination of CE or ce antigens together. A third gene residing in chromosome number 6 codes for Rh associated glycoprotein (RhAG), which is a coexpressor required for successful expression of $\mathrm{Rh}$ antigens. The $\mathrm{Rh}$ antigens are a part of protein complex in the $\mathrm{RBC}$ membrane. Therefore, Rh antigens are only expressed on erythroid line. 
The $\mathrm{D}$ antigen is the most immunogenic of all the non$\mathrm{ABO}$ antigens. Exposure to less than $0.1 \mathrm{~mL}$ of $\mathrm{Rh}$-positive RBCs can stimulate antibody production in an Rh-negative person. Approximately, $80 \%$ of D-negative individuals will produce an anti-D antibody when exposed to a single Dpositive unit.

The $\mathrm{D}$ antigen of $\mathrm{Rh}$ system is the most immunogenic, $\mathrm{C}$ antigen is the next most immunogenic one followed by $\mathrm{E}, \mathrm{C}$ and e. Hence, the immunogenicity of Rh antigens is as follows: $\mathrm{D}>\mathrm{c}>\mathrm{E}>\mathrm{C}>\mathrm{e}$. All Rh antibodies except $\mathrm{D}$ display dosage effect (antibody reacts more strongly with red cells homozygous for an antigen than cells heterozygous for the antigen, eg. EE stronger reaction versus Ee). ${ }^{3}$

$\mathrm{Rh}$ antibodies are of IgG type which is acquired through exposure to Rh-positive blood, either through pregnancy or transfusion of blood products. $\operatorname{IgG}_{1}, \operatorname{IgG}_{2}, \mathrm{IgG}_{3}, \mathrm{IgG}_{4}$ subclasses of $\mathrm{Rh}$ antibodies are reported, of which $\mathrm{IgG}_{1}$ and $\mathrm{IgG}_{3}$ are of greater clinical significance. $\mathrm{Rh}$ antibodies are capable of causing severe haemolytic disease of the foetus and newborn (HDFN or HDN) and haemolytic transfusion reactions with extravascular haemolysis. There are a few examples of IgM type of Rh alloantibody, but they are minimum.

Four sets of investigators have proposed terminologies to describe the Rh system. Two of the terminologies are based on the postulated genetic mechanisms of the Rh system (1) Fisher and Race eg. DCe/ dce, (2) Wiener eg. $R_{1} \mathrm{r}$ (probable genotype $\mathrm{CDe} / \mathrm{cde}$ ). The third terminology- Rosenfield and Associates assigned a number to Rh system antigens (eg. DRh1, C- Rh2, E- Rh3, c- Rh4, e- Rh5). ${ }^{4}$ It describes only the presence or absence of a given $\mathrm{Rh}$ antigen. The fourth terminology is of the International Society of Blood Transfusion committee (ISBT). They adopted a six-digit number for each authenticated antigen of Rh system, eg. D. 004001 (004 assigned for Rh blood group system and each antigen assigned to the system was given a unique number to complete the six-digit computer number).

The $\mathrm{Rh}$ antigens, their prevalence, antigenicity, distribution, patterns of inheritance had been studied extensively in different populations of western world. ${ }^{3}$ The present study is for the purpose of providing information on the frequencies of $\mathrm{Rh}$ antigens among blood donors in Alappuzha district of Kerala.

\section{MATERIALS AND METHODS}

This is a descriptive study done on 500 blood donors who came to the Department of Transfusion Medicine, Govt. T. D. Medical College, Alappuzha, Kerala during the period of February 2015 to February 2016. The donors were selected as per the screening criteria laid down by the Drugs and Cosmetic Act 1940 and Rules 1945. The study population consisted of blood donors, both RhD positive and Rh negative.

Three hundred and fifty (350) $\mathrm{mL}$ of whole blood was collected from each blood donor in single or triple bags containing citrate phosphate dextrose adenine anticoagulant solution. After collection, about $4 \mathrm{~mL}$ of whole blood was taken in a test tube for grouping and phenotyping.

$\mathrm{ABO}$ grouping and $\mathrm{Rh}$ typing were carried out on 500 donor samples by conventional tube method. ABO group of the samples were determined by both forward (cell grouping) and reverse grouping (serum grouping), whereas Rh typing by cell grouping only. Forward grouping was done using monoclonal anti $\mathrm{A}$, anti $\mathrm{B}$, anti $\mathrm{AB}$, anti $\mathrm{H}$ and $\mathrm{Rh}$ typing using monoclonal anti D (Tulip Diagnostic Ltd.). Reverse grouping performed using in-house prepared pooled A cell, B cell and $O$ cells. Donor samples typed as D negative were confirmed by testing for weak D. All reagents were used after subjecting it to quality control test.

$\mathrm{Rh}$ phenotyping was further done by adding equal concentration of IgM monoclonal antisera (Tulip Diagnostics Ltd.) of anti-C, anti-c, anti-E, anti-e and 5\% donor cell suspension in 4 different test tubes. Mixed the contents and kept it for 5 minutes at room temperature. After centrifuging the test tubes for 1 minute at $1000 \mathrm{rpm}$, results were read macroscopically. All the negative reactions were confirmed microscopically also.

Donor blood grouping and $\mathrm{Rh}$ phenotyping data were entered into Microsoft Excel sheet and statistically analysed.

\section{Statistical Analysis}

All statistical data were analysed using SPSS Software version 16. Qualitative or categorical variables were described as frequencies and proportion.

\section{RESULTS}

A total of 500 donors were phenotyped, 470 males (94\%) and 30 female donors (6\%). ABO grouping showed that " 0 " is the most common blood group. Among 500 donors, 183 were blood group " $\mathrm{O}$ " (36.6\%) and " $\mathrm{AB}$ " was the least with 32 donors (6.4\%). In Rh typing, 433 donors (86.6\%) were Rh D positive and 67 donors (13.4\%) were Rh D negative. No weak $\mathrm{D}$ variants have been detected in the study.

\begin{tabular}{|c|c|c|}
\hline Phenotype & Number & Percentage \\
\hline 0 & 183 & $36.6 \%$ \\
\hline B & 149 & $29.8 \%$ \\
\hline A & 136 & $27.2 \%$ \\
\hline $\mathrm{AB}$ & 32 & $6.4 \%$ \\
\hline Total & 500 & $100 \%$ \\
\hline \multicolumn{3}{|c|}{$\begin{array}{c}\text { Table 1. Phenotypic distribution of ABO Blood Group } \\
\text { among Donors }\end{array}$} \\
\hline
\end{tabular}

\begin{tabular}{|c|c|c|c|}
\hline Gender & Male & Female & Total \\
\hline Rh D positive & 408 & 25 & 433 \\
\hline Rh D negative & 62 & 5 & 67 \\
\hline Total & $\mathbf{4 7 0}$ & $\mathbf{3 0}$ & $\mathbf{5 0 0}$ \\
\hline $\begin{array}{c}\text { Table 2. Gender Wise proportion of Rh Negative and } \\
\text { Positive individuals in the Study Population }\end{array}$ \\
\hline
\end{tabular}

\begin{tabular}{|c|c|c|c|c|}
\hline $\begin{array}{c}\text { Sl. } \\
\text { No. }\end{array}$ & $\begin{array}{c}\text { Rh } \\
\text { Antigen }\end{array}$ & $\begin{array}{c}\text { Presence of } \\
\text { Individual } \\
\text { Antigen on } \\
\text { RBC }\end{array}$ & $\begin{array}{c}\text { Percentage of } \\
\text { Individual } \\
\text { Antigen }\end{array}$ & $\begin{array}{c}\text { Antigenic } \\
\text { Frequency }\end{array}$ \\
\hline 1 & R h D & 433 & $86.6 \%$ & 0.8660 \\
\hline 2 & R h C & 404 & $80.8 \%$ & 0.8080 \\
\hline 3 & R h c & 305 & $61 \%$ & 0.6100 \\
\hline 4 & R h E & 62 & $12.4 \%$ & 0.1240 \\
\hline 5 & R h e & 484 & $96.8 \%$ & 0.9680 \\
\hline \multicolumn{5}{|c|}{ Table 3. Frequency distribution of Rh Antigens } \\
\hline
\end{tabular}

The frequency of five $\mathrm{Rh}$ antigens among the donors was assessed. Most common Rh antigen observed in the study population was e - $484(96.8 \%)$ followed by D - $433(86.6 \%)$. 


\begin{tabular}{|c|c|c|c|c|}
\hline $\begin{array}{c}\text { Total No. of } \\
\text { Donors } \\
\text { (N=500) }\end{array}$ & $\begin{array}{c}\mathbf{C} \\
\text { AF (\%) }\end{array}$ & $\begin{array}{c}\mathbf{c} \\
\text { AF (\%) }\end{array}$ & $\begin{array}{c}\mathbf{E} \\
\text { AF (\%) }\end{array}$ & $\begin{array}{c}\mathbf{e} \\
\text { AF (\%) }\end{array}$ \\
\hline Rh D positive & $92.1 \%$ & $54.9 \%$ & $13.8 \%$ & $96.7 \%$ \\
\hline (433) & $\mathrm{N}=399$ & $\mathrm{~N}=238$ & $\mathrm{~N}=60$ & $\mathrm{~N}=419$ \\
\hline Rh D negative & $7.4 \%$ & $100 \%$ & $2.9 \%$ & $97.01 \%$ \\
\hline (67) & $\mathrm{N}=5$ & $\mathrm{~N}=67$ & $\mathrm{~N}=2$ & $\mathrm{~N}=65$ \\
\hline
\end{tabular}

Table 4. Antigen Frequency of Rh Antigens (CcEe) in Rh D Positive and Rh D Negative Blood Donors

We have observed that among the $\mathrm{D}$ negative donors almost $100 \%$ had c antigens and $97.01 \%$ with e antigens on their red cells. C antigen was associated with $92.1 \%$ of $\mathrm{Rh} \mathrm{D}$ positive donors and only in $7.4 \%$ of $\mathrm{Rh} \mathrm{D}$ negative suggesting that $\mathrm{C}$ antigen is more prevalent on $\mathrm{Rh} \mathrm{D}$ positive red cells.

\section{Phenotypic and possible Genotypic distribution Pattern}

In this study, phenotypic and possible genotypic distribution were assessed using different reaction patterns of RBCs from donors to the five Rh antiseras (anti-D, anti-C, anti-c, anti-E, anti-e). From the reaction pattern 10 presumed genotypes were found, most common being DCe/Dce (R1R1-39\%) and $\mathrm{cE} / \mathrm{cE}\left(\mathrm{r}{ }^{\prime \prime} \mathrm{r}^{\prime}-0.4 \%\right)$ was the rarest genotype observed (but exact genotype could not be performed and is a main limitation of this study).

\begin{tabular}{|c|c|c|c|c|c|c|}
\hline D| & C c $\mathbf{c}$ & $\mathbf{E} \mid \mathbf{e}$ & $\begin{array}{l}\text { Pheno } \\
\text {-type }\end{array}$ & \begin{tabular}{|c|} 
Incidence \\
No
\end{tabular} & $\begin{array}{c}\text { Possible } \\
\text { Genotype }\end{array}$ & \begin{tabular}{|c|} 
Most probable \\
Genotype
\end{tabular} \\
\hline+- & +- & -+ & DCCee & $195(39 \%)$ & $\mathrm{R}_{1} \mathrm{R}_{1}, \mathrm{R}_{1} \mathrm{r}^{\prime}$ & $\begin{array}{c}\text { DCe/DCe } \\
\left(\mathrm{R}_{1} \mathrm{R}_{1}\right) \\
\end{array}$ \\
\hline+ & ++ & -+ & DCcee & $\begin{array}{c}173 \\
(34.6 \%) \\
\end{array}$ & $\mathrm{R}_{1} \mathrm{R}_{0}, \mathrm{R}_{1} \mathrm{r}, \mathrm{R}_{0} \mathrm{r}^{\prime}$ & $\mathrm{DCe} / \mathrm{dce}\left(\mathrm{R}_{1} \mathrm{r}\right)$ \\
\hline- & -+ & -+ & dccee & $60(12 \%)$ & $\mathrm{rr}$ & dce/dce (rr) \\
\hline+ & -+- & ++ & DccEe & $25(5.05 \%)$ & $\mathrm{R}_{2} \mathrm{R}_{0}, \mathrm{R}_{2} \mathrm{r}, \mathrm{R}_{0} \mathrm{r}^{\prime \prime}$ & DcE/dce $\left(\mathrm{R}_{2} \mathrm{r}\right)$ \\
\hline+ & ++ & ++ & DCcEe & $21(4.3 \%)$ & \begin{tabular}{|c|}
$\mathrm{R}_{1} \mathrm{R}_{2}, \mathrm{Rzr}, \mathrm{R}_{2} \mathrm{r}^{\prime}$, \\
$\mathrm{R}_{1} \mathrm{r}^{\prime \prime}$ \\
\end{tabular} & $\mathrm{DCe} / \mathrm{DcE}\left(\mathrm{R}_{1} \mathrm{R}_{2}\right)$ \\
\hline+ & ++- & + & DCcEE & $10(1.97 \%)$ & $\mathrm{R}_{2} \mathrm{Rz}, \mathrm{R}$ & $\left(\mathrm{R}_{2} \mathrm{Rz}\right)$ \\
\hline 4 & -+ & -4 & Dccee & $5(1 \%)$ & R0R0,R0ry & Dce/Dce $\left(\mathrm{R}_{0} \mathrm{R}_{0}\right)$ \\
\hline$-5-$ & ++ & $-5+$ & dCcee & $5(1 \%)$ & r'r & dCe/dce (r'r) \\
\hline+ & -+- & +- & DccEE & $4(0.87 \%)$ & $\mathrm{R}_{2} \mathrm{R}$ & DcE/DcE $\left(R_{2} R_{2}\right)$ \\
\hline- & -+1 & & dccEE & $2(0.4 \%)$ & $r^{\prime \prime} r^{\prime \prime}$ & dcE/dcE (r"r") \\
\hline
\end{tabular}

\section{DISCUSSION}

The present study gives an insight into the pattern of distribution of $\mathrm{ABO}$ and $\mathrm{Rh}$ antigens among blood donors coming to Department of Transfusion Medicine, Govt. T. D. Medical College, Alappuzha, which is a tertiary care centre in Kerala. The aim of the study was to phenotype the 5 major types of $\mathrm{Rh}$ antigens in blood donors, to determine the $\mathrm{Rh}$ composition of the population in Kerala and to generate a database of donors for all future activities.

$\mathrm{ABO}$ grouping showed " $\mathrm{O}$ " as the most predominant blood group (36.6\%) followed by "B" $(29.8 \%)$ and " $A B$ " the least (6.4\%). Most of the literature from India support the fact that incidence of 0 is more in Indian population, 5,6 except few studies such as one conducted at Department of Transfusion Medicine, Chhatrapati Shahuji Maharaj Medical University, Lucknow by Tulika Chandra and Ashish Gupta 4 observed "B" (35.08\%) as more prevalent than $O$ (26.31\%). Among 500 samples, $86 \%(n=433)$ were found to be $R h D$ positive and the remaining $13.4 \%(n=67)$ were $\mathrm{Rh} D$ negative. Similar studies by Sarkar et al at Armed Force Medical College, Pune and in South India by Das et $\mathrm{al}^{7}$ from Dr. John Scudder Memorial Blood Bank, Christian Medical College Hospital, Vellore, showed a predominance of Rh D positive (94.53\%) among their blood donors. In our study, the relatively increased number of Rh D negative donors (13.4\%) may be due to the coincidental random selection of donors when there was a higher demand for Rh D negative blood.

All the $\mathrm{Rh} \mathrm{D}$ negative cells were tested for weak $\mathrm{D}$ by indirect antiglobulin test. Not even a single individual was observed having weak Rh D variant during the course of our study. The incidence of weak D antigen ranges from $0.2 \%-1 \%$ worldwide. Studies conducted in India showed an incidence of $0.189 \%$ and $0.15 \% .8,9$

Most common $\mathrm{Rh}$ antigen observed in the study population was e $(96.8 \%)$ followed by D $(86.6 \%)$, C $(80.8 \%)$, c (61\%) and at last $\mathrm{E}(12.4 \%)$. The frequency of $\mathrm{C}$ antigen in our study was $80.8 \%$, which is comparable with the findings of study by Thakral $(84.76 \%)$. The c antigen was found to be positive in $61 \%$ of our samples; however, it is little higher than what was shown in the study by Thakral et al (52.82\%).10

We have observed that among the $\mathrm{D}$ negative donors, almost $100 \%$ had $\mathrm{c}$ antigens and $97 \%$ with e antigens on their red cells. Thus, there is strong association of $\mathrm{c}$ antigen and $\mathrm{e}$ antigen with D negative donors. This finding is similar to the finding seen in a study by DS Lamba, Ravneet Kaur and Sabita Basu11 from Government Medical College, Chandigarh.

In the present study, $\mathrm{C}$ antigen was found to be more associated with $\mathrm{D}$ antigen. A significant difference was noted in the frequency of $\mathrm{C}$ antigen among $\mathrm{Rh} \mathrm{D}$ positive and $\mathrm{D}$ negative donors. $\mathrm{C}$ antigen was associated with $79.8 \%$ of $\mathrm{Rh} \mathrm{D}$ positive donors and only in $7.4 \%$ of $\mathrm{Rh} \mathrm{D}$ negative suggesting that $\mathrm{C}$ antigen is more prevalent on $\mathrm{Rh} \mathrm{D}$ positive red cells. Similar finding was observed in the study conducted by Lamba et al, of $\mathrm{C}$ antigen with $\mathrm{Rh} \mathrm{D}$ cells showing the association $(90.8 \%)$.

\section{CONCLUSION}

This is a descriptive study done on 500 blood donors who came to the Department of Transfusion Medicine, Govt. T. D. Medical College, Alappuzha. The study was done to analyse the frequencies of different $\mathrm{Rh}$ antigens and its phenotypes among blood donors.

Among the 500 blood donors included in the study, 30 (6\%) were females and 470 (94\%) were males. ABO grouping showed " $O$ " as the most predominant blood group (36.6\%) followed by "B" (29.8\%) and "AB" the least (6.4\%). 86.6\% $(n=433)$ of the donors were found to be Rh D positive and the remaining $13.4 \%(n=67)$ were $R h D$ negative. This relative increase in $\mathrm{Rh} \mathrm{D}$ negative population may be due to the coincidental random selection of donors when there was a higher demand for $\mathrm{Rh} \mathrm{D}$ negative blood. The percentage of $\mathrm{Rh}$ D negative females according to the current study was $1 \%$, whereas in males it was $12.4 \%$.

Most common $\mathrm{Rh}$ antigen observed in the study population was e $(96.8 \%)$ followed by D $(86.6 \%)$, C (80.8\%), c (61\%) and at last E (12.4\%). Out of $433 \mathrm{Rh} \mathrm{D}$ positive randomly selected blood donors in the study, the most common phenotype was found to be R1R1 (39\%) followed by R1r (34.6\%). Among $67 \mathrm{Rh}$ D negative subjects, ccdee (rr) was the commonest phenotype (60 out of 67 ). 
Knowledge of Antigen Frequency (AF) in the given population is clinically important as one can predict the common alloantibodies that can develop in multi-transfused patients. Once an antibody has developed due to alloimmunisation, the only blood that can be transfused without harm would be the corresponding antigen negative blood. For instance, according to this study if a patient with alloantibody against $\mathrm{C}$ and requiring two units of blood, a minimum of 40 units of $\mathrm{ABO}$ matched blood will need to be cross-matched to get 2 units of compatible antigen negative blood (since $\mathrm{C}$ negative constitutes $19.2 \%$ of all 500 donors). Another advantage of knowing AF is that it helps in selection of antigen negative units for transfusion.

This study has provided us a blood donor database with known antigenic profile, which is most vital for a quality transfusion practice.

\section{REFERENCES}

[1] Giangrande PL. The history of blood transfusion. British Journal of Haematology 2000;110(4):758-67.

[2] Poole J, Daniels G. Blood group antibodies and their significance in transfusion medicine. Transfusion Medicine Reviews 2007;21(1):58-71.

[3] Reid ME, Francis CL. The blood group antigen factsbook. $2^{\text {nd }}$ edn. Academic Press 2004.

[4] Rosenfield RE, Allen FH Jr, Swisher SN, et al. A review of Rh serology and presentation of a new terminology. Transfusion 1962;2:287-312.
[5] Chandra T, Gupta A. Frequency of ABO and Rhesus blood groups in blood donors. Asian J Transfusion Sci 2012;6(1):52-3.

[6] Kaur H, Khanna A, Manjari M, et al. Prevalence of ABO blood groups and Rhesus (Rh) factor in the population residing in and around Amritsar, Punjab (a 4 year study from June 2007 to June 2011). Asian Journal of Transfu Sci 2013;7(2):159.

[7] Das PK, Nair SC, Harris VK, et al. Distribution of ABO and Rh-D groups among blood donors in a tertiary care centres in South India. Trop Doct 2001;31(1):478.

[8] Kumar H, Mishra DK, Sarkar RS, et al. Difficulties in immunohematology: the weak $\mathrm{D}$ antigen. MJAFI 2005;61(4):348-50.

[9] Bhatia HM. Mumbai: Blood Group Reference Centre, Indian Council of Medical Research 1977:44.

[10] Thakral B, Saluja K, Sharma RR, et al. Red cell alloimmunization in transfused patient population: a study from a tertiary care hospital in North India. Hematology 2008;13(5):313-8.

[11] Lamba DS, Kaur R, Basu S. Research article clinically significant minor blood group antigens amongst North Indian donor population. Article ID 215454, Advances in Hematology 2013;2013: p. 5. 